\title{
THE QuALITY OF Volatility Traded ON \\ THE OVER-THE-COUNTER \\ CURRENCY MARKET: A \\ Multiple Horizons \\ STUDY
}

\section{VICENTIU COVRIG* BUEN SIN LOW}

Previous studies of the quality of market-forecasted volatility have used the volatility that is implied by exchange-traded option prices. The use of implied volatility in estimating the market view of future volatility has suffered from variable measurement errors, such as the non-synchronization of option and underlying asset prices, the expiration-day effect, and the

\footnotetext{
The authors thank Yong Cher for his research assistance, and Louis Ederington, Michael Melvin, Lilian Ng, Gunter Dufey, Robin Grieves, Phillipe Chen, the participants at the CREFS workshop at the Nanyang Business School, and those at the 2001 FMA Annual Meeting in Toronto for their helpful comments. The authors also thank the Journal of Futures Markets editor, Robert I. Webb, and an anonymous referee for helpful comments.

Support for this project was provided by the CREFS at the Nanyang Business School.

*Corresponding author, School of Management, University of Michigan-Dearborn, 4901 Evergreen Road, Dearborn, Michigan 48128-1491; e-mail: vcovrig@umd.umich.edu
}

Received December 2001; Accepted August 2002

- Vicentiu Covrig is an assistant professor in the School of Management at the University of Michigan-Dearborn, Michigan.

- Buen Sin Low is an assistant professor in the Division of Banking and Finance and the deputy director of the Center for Financial Engineering at the Nanyang Technological University, Singapore. 
volatility smile effect. This study circumvents these problems by using the quoted implied volatility from the over-the-counter (OTC) currency option market, in which traders quote prices in terms of volatility. Furthermore, the OTC currency options have daily quotes for standard maturities, which allows the study to look at the market's ability to forecast future volatility for different horizons. The study finds that quoted implied volatility subsumes the information content of historically based forecasts at shorter horizons, and the former is as good as the latter at longer horizons. These results are consistent with the argument that measurement errors have a substantial effect on the implied volatility estimator and the quality of the inferences that are based on it. (C) 2003 Wiley Periodicals, Inc. Jrl Fut Mark 23:261-285, 2003

\section{INTRODUCTION}

Previous studies of the quality of market-forecasted future volatility in currency options have used implied volatilities from exchange-traded currency options markets. Generally, they found that implied volatility has substantial informational content, and that it outperforms historically based volatility forecasts, but it is still biased. However, such empirical results are likely to be affected by two sources of well-documented errors: measurement errors in model inputs and errors in the option pricing model that is used for computation. The errors in model inputs can arise from bid-ask spreads, non-synchronization in option and underlying asset prices, different closing times of exchanges, maturity mismatches, the expiration-day effect, and the time-varying maturity of exchange-traded options, as discussed in numerous studies (e.g., Canina \& Figlewski, 1993; Christiansen \& Prabhala, 1998; Day \& Lewis, 1992; Figlewski, 1997; Fleming, 1998; Jorion, 1995). Furthermore, studies that are based on exchange-traded options also are likely to suffer from potential noise from the volatility smile effect. Exchange-traded options have fixed strike prices, and as the underlying asset price changes, such option contracts may become more or less in the money or out of the money. It is very unlikely that the option is exactly at the money, and thus the implied volatility from an option pricing model that has not accounted for the smile effect is likely to be subjected to error.

This article differs from previous studies in that it uses quoted implied volatility data from the OTC currency option market. ${ }^{1}$ The

\footnotetext{
${ }^{1}$ Campa and Chang (1995) also employed quoted implied volatility in their study. However, their objective differed from this study in that they investigated whether forward quoted implied volatility had any predictive power for future quoted implied volatility. Their data was supplied by a major commercial bank. The data that is employed in this study was obtained from Bloomberg, which collected them from major quoting banks.
} 
institutional features of the OTC market alleviate the measurement problems that are found in studies that use implied volatility that is derived from exchange-traded option prices. ${ }^{2}$ Unlike exchange-traded currency option markets in which market players quote option prices in terms of option premiums, in the OTC currency option market the price quotes actually are made in terms of volatility, which is expressed as a percentage per annum. For example, an option might be quoted as a $10 \%$ bid that then would be translated into option premiums by introducing the volatility figure into the Garman-Kohlhagen model, along with the current spot exchange rate and domestic and foreign interest rates at that point in time. Strictly speaking, quoted implied volatility is a form of implied volatility. Virtually every article in the option literature uses exchange-traded options with varying maturities. In contrast, the OTC currency options used in this study have constant maturity and always are traded at the money, which leads to more stationarity in data and less specification errors. Furthermore, the OTC currency option market is substantially more liquid than the exchange-traded currency option market. The annual turnover of currency options that are traded on organized exchanges was about US\$1.3 trillion in 1995 and declined to US\$0.5 trillion in $1998,{ }^{3}$ whereas the annual turnover on the over-the-counter market was about US\$10.25 trillion in 1995 and US $\$ 21.75$ trillion in $1998 .^{4}$

Thus, the importance of this study is in exploring the OTC currency options market, which has distinct institutional characteristics that obviate the measurement errors that are found in previous studies, to address the following questions. Firstly, what is the quality of market-predicted volatility when the data does not suffer from some of the problems that were mentioned earlier? Secondly, does the market's ability to forecast future volatility vary with the forecasting horizon? The unique features of the OTC market allow us to test this hypothesis because only within that market are there daily quotes for currency options with standard maturities.

Specifically, this study compares the predictive power of quoted implied volatility for options with standard maturities of 1,2, 3, and 6 months with volatility forecasts that are derived from historical data.

\footnotetext{
${ }^{2}$ However, this study does not account for the effect of option-pricing-model misspecification on the quality of the implied volatility. Empirical studies that account for model misspecification include Amin and $\mathrm{Ng}$ (1997), who employed several interest-rate option models to study the quality of implied volatility in Eurodollar futures options, and Poteshman (2000), who used a stochastic volatility model to study the quality of implied volatility in S\&P 500 index option.

${ }^{3}$ See Bank for International Settlement (2000) for details.

${ }^{4}$ See Bank for International Settlement (1999) for details.
} 
Three widely used methods are employed to compute the volatility forecast from historical spot exchange rates: historical standard deviation, the Generalized AutoRegressive Conditional Heteroskedasticity (GARCH) $(1,1)$ model, and the Exponentially Weighted Moving Average (EWMA) model that is presented in J. P. Morgan's RiskMetrics ${ }^{\mathrm{TM}}$. Because OTC data has been collected systematically only recently, the limited data span-June 5, 1996 to April 25, 2000-makes it important to use fully all of the information in the sample. Thus, the tests are conducted using daily data for GBP/USD (U.S. dollars per British pound), USD/JPY (Japanese yen per U.S. dollar), and AUD/USD (U.S. dollars per Australian dollar) contracts. ${ }^{5}$

The results of this study show that market-forecasted volatility is a good estimator of future volatility, even when matched with more sophisticated historical time-series-based conditional volatility estimates from the GARCH and EWMA models. Differing from previous studies, this study also finds that quoted implied volatility generally is an unbiased estimator of future volatility at the shorter forecasting horizon for all of the currencies that are studied. As previous results were robust across time, and because there is no reason to believe that traders on the OTC currency market are better than those in other markets, the plausible explanations of the differences in the results are: (i) the importance of measurement errors, and (ii) the higher liquidity on the OTC market, which is consistent with the Figlewski (1997) hypothesis that the informational content of quoted implied volatility is related positively to liquidity. However, the quoted implied volatility is still a biased estimator for longer horizons, and its superior forecasting ability diminishes as the forecasting horizon increases. Nevertheless, as options with longer terms of maturity have lower liquidity than shorter-term options, this observation supports Figlewski's liquidity hypothesis.

\section{LITERATURE REVIEW}

Scott (1992) examined whether implied volatility less intraquarterly historical volatility would have been useful for forecasting changes in future intraquarterly volatility from 1983 to 1989 . He found that the implied volatility from British pound, Deutsche mark, and Swiss franc spot options that were traded on the Philadelphia Stock Exchange (PHLX) is

\footnotetext{
${ }^{5}$ The data that kindly has been provided for this study contains only these three pairs of currencies. These exchange-rate quotations are used as they are in line with the practice of the OTC currency market.
} 
informative and close to being an unbiased forecast of future volatility, but that the implied volatility from the Japanese yen had no informational content. Using ARCH-based volatility forecasts and a new methodology that accounts for the term structure of volatility expectations, $\mathrm{Xu}$ and Taylor (1995) found that PHLX implied volatilities provide specifications for daily conditional variance that cannot be improved significantly by using past returns. In contrast, Taylor and Xu (1997) showed that when using high-frequency exchange rates, historically based forecasts of volatility provide information that is additional to the information found in option prices.

Jorion (1995) investigated Deutsche mark, Japanese yen, and Swiss franc futures options that were listed on the Chicago Mercantile Exchange from 1985 to 1992 and found that implied volatility, while it outperforms other volatility forecasts, is still biased. Bodurtha and Shen (1995) reached a similar conclusion with regard to the forecasting ability of implied volatility from Deutsche mark and Japanese yen spot options that were listed on the PHLX in a more recent period-1991 to 1994. Bates (1996) looked at the weekly volatility forecasts from Deutsche mark and Japanese yen spot options that were listed on the PHLX from 1984 to 1992 and showed that implied volatility has substantial informational content, but rejects the unbiasedness hypothesis. Using a different approach to extracting the implied variance from option prices, Guo (1998) also found that daily currency implied volatility is a biased forecast of future volatility. Thus, extant studies have suggested that the implied volatility derived from exchange-traded currency option prices is a biased and inefficient estimate of future volatility. However, as mentioned earlier, the use of implied volatility from the exchange-traded option market in estimating the market view of future volatility suffers from measurement errors such as the non-synchronization of option and underlying asset prices, the expiration-day effect, and the volatility smile effect. Using simulations, Jorion (1995) found that the above-mentioned sources of measurement error could substantially distort inferences and account for a significant part of the biases that are associated with the tests of the predictive power of implied volatility. ${ }^{6}$

This study circumvents these problems by using quoted implied volatility from the OTC currency option market, in which traders quote prices in terms of volatility. Furthermore, the OTC currency options

\footnotetext{
${ }^{6}$ The simulation results of Jorion (1995) showed that when accounting for possible measurement errors and statistical problems, the slope of the volatility forecast is 0.907 , as compared to the actual slope of 0.547 .
} 
have daily quotes for standard maturities, which allows an investigation of the market's ability to forecast future volatility for different horizons.

\section{DATA AND METHODOLOGY}

\section{Data and Descriptive Statistics}

The data set that is employed consists of daily average bid and ask closing volatility quotes of GBP/USD (U.S. dollars per British pound), USD/JPY (Japanese yen per U.S. dollar), and AUD/USD (U.S. dollars per Australian dollar) OTC options from June 5, 1996, to April 25, 2000. There are 12,180 observations, with an average of 1015 observations per currency pair in each maturity period.

Specifically, the data represent quoted implied volatility prices that correspond to the at-the-money forward straddles (i.e., one European call plus one European put, the common strike price of which equals the forward rate) with standard maturities of $1,2,3$, and 6 months. The at-themoney forward-straddle quotes are used because the interbank OTC currency options frequently are traded in combinations, and the most liquid combination is the at-the-money forward straddle. Both the quoted implied volatility and spot exchange rates were obtained from Bloomberg, who collected them from the interbank OTC market.

The actual or realized volatility is calculated from the spot exchange rates using market conventions ${ }^{7}$ over the option period, that is, from the quotation date to the expiration date of the option. For example, a onemonth option contract that was quoted on February 8, 2000, would expire on March 8, 2000, with settlement two business days later, on March 10, 2000. The standard deviation is calculated using the continuously compounded daily spot returns from February 8, 2000, to March 8, 2000, and annualized.

Table I presents the summary statistics for the natural logarithm of the quoted implied volatility and actual volatility for the USD/JPY, GBP/USD, and AUD/USD currency pairs. The log series is chosen due to better normality properties. ${ }^{8}$ The quoted implied volatility series are based on the average of the bid and ask prices on 1-, 2-, 3-, and 6-month options.

\footnotetext{
${ }^{7}$ Bruer and Wohar (1996) discussed how ignoring foreign-exchange market conventions on sampling data can lead to biased estimates.

${ }^{8}$ The descriptive statistics for the level of the actual and quoted implied volatility are available from the authors upon request. Other studies that used log volatility series are those of Christensen and Prabhala (1998) and Poteshman (2000).
} 
TABLE I

Descriptive Statistics for Quoted Implied and Actual Volatility

\begin{tabular}{|c|c|c|c|c|c|c|c|c|}
\hline \multicolumn{2}{|c|}{ Variable } & Mean & $S D$ & Skewness & Kurtosis & Autocorrelation & Minimum & Maximum \\
\hline \multicolumn{9}{|c|}{ USD/JPY } \\
\hline AV & $1 \mathrm{M}$ & 2.407 & 0.361 & 0.342 & 3.307 & 0.978 & 3.485 & 1.416 \\
\hline QIV & $1 \mathrm{M}$ & 2.486 & 0.279 & -0.108 & 2.895 & 0.941 & 3.323 & 1.792 \\
\hline AV & $2 \mathrm{M}$ & 2.448 & 0.325 & 0.263 & 2.967 & 0.992 & 3.344 & 1.801 \\
\hline QIV & $2 \mathrm{M}$ & 2.505 & 0.255 & -0.217 & 2.806 & 0.950 & 3.188 & 1.879 \\
\hline AV & $3 \mathrm{M}$ & 2.476 & 0.308 & 0.087 & 2.807 & 0.995 & 3.224 & 1.817 \\
\hline QIV & $3 \mathrm{M}$ & 2.522 & 0.241 & -0.233 & 2.704 & 0.956 & 3.114 & 1.895 \\
\hline AV & $6 \mathrm{M}$ & 2.547 & 0.256 & -0.044 & 3.366 & 0.995 & 3.078 & 1.954 \\
\hline QIV & $6 \mathrm{M}$ & 2.555 & 0.225 & -0.280 & 2.469 & 0.956 & 3.001 & 2.001 \\
\hline \multicolumn{9}{|c|}{ AUD/USD } \\
\hline AV & $1 \mathrm{M}$ & 2.218 & 0.351 & 0.072 & 3.030 & 0.980 & 3.127 & 1.095 \\
\hline QIV & $1 \mathrm{M}$ & 2.272 & 0.286 & -0.081 & 2.352 & 0.959 & 3.033 & 1.609 \\
\hline AV & $2 \mathrm{M}$ & 2.251 & 0.318 & -0.115 & 2.440 & 0.993 & 2.966 & 1.462 \\
\hline QIV & $2 \mathrm{M}$ & 2.242 & 0.268 & -0.110 & 2.385 & 0.963 & 2.996 & 1.629 \\
\hline AV & $3 \mathrm{M}$ & 2.277 & 0.289 & -0.149 & 2.153 & 0.995 & 2.831 & 1.536 \\
\hline QIV & $3 \mathrm{M}$ & 2.220 & 0.260 & -0.133 & 2.300 & 0.964 & 2.890 & 1.649 \\
\hline AV & $6 \mathrm{M}$ & 2.330 & 0.239 & -0.299 & 2.023 & 0.996 & 2.734 & 1.822 \\
\hline QIV & $6 \mathrm{M}$ & 2.172 & 0.250 & -0.131 & 2.217 & 0.963 & 2.757 & 1.649 \\
\hline \multicolumn{9}{|c|}{ GBP/USD } \\
\hline AV & $1 \mathrm{M}$ & 1.967 & 0.271 & -0.220 & 3.062 & 0.964 & 2.601 & 1.141 \\
\hline QIV & $1 \mathrm{M}$ & 2.082 & 0.204 & -0.982 & 4.308 & 0.935 & 2.674 & 1.361 \\
\hline AV & $2 \mathrm{M}$ & 1.999 & 0.209 & -0.430 & 3.748 & 0.983 & 2.450 & 1.264 \\
\hline QIV & $2 \mathrm{M}$ & 2.103 & 0.176 & -1.221 & 4.993 & 0.934 & 2.595 & 1.459 \\
\hline AV & $3 \mathrm{M}$ & 2.025 & 0.153 & -0.137 & 2.885 & 0.984 & 2.377 & 1.565 \\
\hline QIV & $3 \mathrm{M}$ & 2.121 & 0.156 & -1.327 & 5.721 & 0.927 & 2.518 & 1.504 \\
\hline AV & $6 \mathrm{M}$ & 2.025 & 0.100 & -0.231 & 2.468 & 0.991 & 2.217 & 1.786 \\
\hline QIV & $6 \mathrm{M}$ & 2.157 & 0.094 & 0.325 & 2.310 & 0.927 & 2.442 & 1.981 \\
\hline
\end{tabular}

Note. This table summarizes the mean, standard deviation, minimum, maximum, kurtosis, skewness, and the first-order autocorrelation of the logarithm of quoted implied volatility (QIV) and actual volatility (AV) for options that have 1 month (1M), 2 months (2M), 3 months (3M), and 6 months $(6 \mathrm{M})$ to expiration. The three currency pairs are USD/JPY (Japanese yen per U.S. dollar), GBP/USD (U.S. dollars per British pound), and AUD/USD (Australian dollars per U.S. dollar). The statistics are computed from 1015 daily observations per currency pair for each maturity period from June 5, 1996, to April 25, 2000.

The following observations can be made from Table I. Firstly, there are no systematic differences in the mean quoted implied volatility and mean actual volatility. The mean quoted implied volatility is greater than the mean actual volatility for USD/JPY and GBP/USD, but not for AUD/USD. This is similar to the Jorion (1995) findings on the relationships between implied volatility and actual volatility. Secondly, the mean actual volatility increases with the time horizon, whereas the relationship between the mean quoted implied volatility and the time horizon is mixed. 
The mean quoted implied volatility for AUD/USD decreases with the horizon, whereas those for GBP/USD and USD/JPY show a positive term structure of quoted implied volatility. Thirdly, and consistent with previous studies on the term structure of volatility (Campa \& Cheng, 1995; Xu \& Taylor, 1994), there is a decrease in the standard deviation of both quoted and actual volatilities with the maturity. For the GBP/USD pair, the standard deviation of 1 -month quoted implied volatility is 0.204 , which is two times the standard deviation of the 6-month quoted implied volatility of 0.094 . For the same currency pair, the standard deviation of 1 -month actual volatility is 0.271 , which is 2.7 times higher than the standard deviation of the 6-month contract at 0.100. Consistent across currencies, the longer horizon contracts are less variable than the shorter contract. Campa and Chang $(1995,1998)$ attributed these findings to the property of mean reversion of the short-dated currency volatility.

The unit root tests show that the volatilities are marginally stationary. According to the autocorrelation statistics in Table I, all volatility series have very high autocorrelation. For example, for the 1-month USD/JPY contract, the first lag autocorrelation is 0.941 for the quoted implied volatility and 0.978 for the actual volatility. These findings are typical for series with overlapping data and are consistent with other studies that use implied volatility. Although not reported here, the autocorrelation and partial correlation functions indicate that all of the series experience mean reversion and are characterized by a first-order autoregressive process. Jorion (1995) showed that autocorrelation in the volatility series causes a downward bias in the Ordinary Least Squares (OLS) standard errors. Drawing from the literature, the present study takes this into account by using the Newey and West (1987) method that provides consistent estimates of the covariance matrix in the presence of both heteroskedasticity and autocorrelation.

\section{Time-Series Volatility Forecasts}

Three widely used methods are employed to calculate volatility forecast based on historical return data.

\section{Historical Standard Deviation}

Several historical standard-deviation time series are constructed from spot exchange rates to match the forecasting horizon for each of the option maturity. This is done by computing the annualized standard deviation of spot-exchange-rate log returns over 23 business days before 
the forecast day for the 1-month contract, 46 business days for the 2-month contract, 69 business days for the 3-month contract, and 138 business days for the 6-month contract.

\section{GARCH-Based Volatility Forecast}

One way to provide conditional forecasts is by using a GARCH methodology that directly models the time-varying volatility. This article adopts the $\operatorname{GARCH}(1,1)$ specification, which was employed by Jorion (1995) and Bodurtha et al. (1995), among others. Further tests of alternative GARCH specifications also are carried out, but it is found that the $\operatorname{GARCH}(1,1)$ model is the most appropriate. The $\operatorname{GARCH}(1,1)$ model is as follows:

$$
\begin{aligned}
& \widetilde{r}_{t}=\bar{r}+\widetilde{\varepsilon_{t}}, \quad \widetilde{\varepsilon_{t}} \sim N\left(0, h_{t}\right) \\
& h_{t}=\beta_{0}+\beta_{1} \widetilde{\varepsilon}_{t-1}^{2}+\beta_{2} h_{t-1}
\end{aligned}
$$

where $\widetilde{r}_{t}$ is the continuously compounded return of the spot exchange rate, $\bar{r}$ is the mean daily return, and $h_{t}$ is the conditional variance. In the variance equation, $\beta_{0}$ represents the mean variance, $\beta_{1}$ is the coefficient on the squared forecast-error term, and $\beta_{2}$ is the coefficient on the lagged conditional-variance term. The interpretation of this specification is that a trader predicts the next period variance from a weighted average of the long-term average variance, the forecasted variance from the last period, and the information about the volatility that was observed in the previous period.

Using Equation 1, on any day $t$, a one-day-ahead forecast of volatility is constructed. For horizons of one month or more, the T-days-ahead forecast is obtained by using recursive substitution in the variance equation. To obtain a GARCH forecast that directly is comparable to the quoted implied volatility, the $h_{t+1}$ to $h_{t+T}$ forecasts are constructed and the Kroner, Kneafsey, and Claessens (1994) procedure is used:

$$
h_{t, t+T}=\sum_{i=1}^{T} h_{t+i}
$$

where $T$ is the number of days ahead to forecast, and $h_{t, t+T}$ is the forecasted variance at time $t$ over the next $T$ days. This then is multiplied by the appropriate factor, and the square root is taken to yield the "annualized" GARCH $(1,1)$ volatility forecast.

To ensure that the volatility forecasts only make use of information that is available to traders at the time when the forecasts are made, this study uses a rolling $G A R C H$, in which a moving window of a fixed number 
of daily observations is used. On each day, observations over the last 1000 days are used to estimate the ARCH and GARCH coefficients, which then are used to compute the forecasts over the various horizons, from 1 to 6 months, for that day. In this way, the out-of-sample forecasts of volatility are obtained to match against the other volatility measures.

\section{RiskMetrics $^{\mathrm{TM}}$ (EWMA) Volatility}

J. P. Morgan developed the Exponentially Weighted Moving Average (EWMA) model as an alternative to the GARCH model for estimating future volatility. ${ }^{9}$ The name of the model comes from the fact that forecasted volatility is an exponentially weighted sum of historical squared returns, with the weights declining geometrically the farther back in time that one goes. The strength of the model is the ease of estimation due to a particularly simple formula for updating volatility estimates:

$$
h_{t+1}=\lambda h_{t}+(1-\lambda) r_{t}^{2}
$$

where $h_{t+1}$ is the one-day-ahead variance forecast, $h_{t}$ is the one-day forecast variance made at day $t, r_{t}^{2}$ is the squared-return innovation, and $\lambda$ is the decaying factor that determines the relative weights that are applied to past observations. By recursive substitution of $h_{t}$ in Equation 3, the following equation is obtained:

$$
h_{t+1}=(1-\lambda) \sum_{t=1}^{N} \lambda^{t-1} r_{t}^{2}
$$

where $N$ is the number of previous return innovations used in forecasting the variance. Consistent with RiskMetrics ${ }^{\mathrm{TM}}, \lambda$ is set equal to 0.94 and $N=74$ days. An advantage of the RiskMetrics estimator is that it gives more weight to recent returns, whereas the usual volatility estimator weights all returns equally over the horizon at which past volatility is estimated. To obtain volatility forecasts for the $T$-day horizon, the square root of $h_{t+1}$ is multiplied by $\sqrt{T}$.

\section{Methodology}

The main hypothesis is that the quoted implied volatility from the OTC market is a better predictor of future volatility than are forecasts based on historical data. The model used to test this is:

$$
\ln \sigma_{t, T}^{\mathrm{AV}}=\alpha_{0}+\alpha_{1} \ln \sigma_{t, T}^{\mathrm{QIV}}+\alpha_{2} \ln \sigma_{t, T}^{\mathrm{HV}}+u_{t}
$$

${ }^{9}$ See J. P. Morgan (1996, pp. 78-82) for details. 
where $\sigma_{t, T}^{\mathrm{AV}}$ denotes the actual volatility over the period $t$ to $t+T$, and $\sigma_{t, T}^{\mathrm{QIV}}$ is the quoted implied volatility that is observed at time $t$ for a contract that expires on $t+T . \sigma_{t, T}^{\mathrm{HV}}$ is the volatility forecast over the period $t$ to $t+T$, which is computed using the historical standard deviation, $\operatorname{GARCH}(1,1)$ or RiskMetrics EWMA models. All of the volatility measures are standard deviations, and the variables are in log form.

Variations of Equation 5 are used to analyze the forecasting power of quoted implied volatility and historically based volatility forecasts independently and jointly in a multiple-regression setting. Several hypotheses are tested.

Firstly, if quoted volatility is informative about future volatility, $\alpha_{1}$ should be statistically different from zero. Secondly, an $\alpha_{0}$ that is equal to zero and an $\alpha_{1}$ that is equal to one are the sufficient conditions for quoted volatility to be unbiased. ${ }^{10}$ Thirdly, if quoted implied volatility is an informationally efficient forecast of future volatility, then $\alpha_{2}$ should be zero when the historically based volatility forecast is regressed jointly with quoted implied volatility. The above are three standard hypotheses that are employed in the literature to study the information content of market volatility. A fourth hypothesis is explored in this study. The data set allows the study to test whether the forecasting ability of quoted implied volatility is related negatively to the forecasting horizon. If the hypothesis is true, then the $\alpha_{1}$ coefficient should decrease in economic and statistical significance with the time horizon.

\section{EMPIRICAL RESULTS}

\section{Univariate Regression Tests}

OLS estimates of Equation 5 are carried out with quoted implied volatility, historical, GARCH, and EWMA volatilities as independent variables. The results are presented in Table II. As the actual volatility is constructed from overlapping daily returns, the OLS estimates are unbiased and efficient, but standard errors are biased downwards. The Newey-West (1987) method, with the number of lags equal to the number of days in the forecasting horizon, is used in computing the $t$-statistics to correct for heteroskedasticity and autocorrelation in the residuals that are caused by this overlapped data.

When quoted implied volatility is the independent variable in Equation 5, all of the currencies at each forecasting horizon (except

\footnotetext{
${ }^{10}$ Taylor (1999) argued that an $\alpha_{0}$ that is equal to zero and an $\alpha_{1}$ that is equal to one are sufficient but not necessary conditions.
} 
TABLE II

Information Content of Quoted Implied Volatility vs. Historical, GARCH, and EWMA Volatility

\begin{tabular}{|c|c|c|c|c|c|c|c|c|}
\hline Horizon & $\begin{array}{l}\alpha_{0} \\
c t .\end{array}$ & $\begin{array}{l}\alpha_{1} \\
I V\end{array}$ & $H V$ & $\begin{array}{c}\alpha_{2} \\
E W M A\end{array}$ & GARCH & $A d-R^{2}$ & F1-stat & F2-stat \\
\hline \multicolumn{9}{|c|}{ Panel A: USD/JPY } \\
\hline \multirow[t]{7}{*}{$1 \mathrm{M}$} & $\begin{array}{c}0.31^{*} \\
(0.15)\end{array}$ & $\begin{array}{c}0.83^{\star \dagger} \\
(0.13)\end{array}$ & & & & 0.41 & 4.54 & \\
\hline & $\begin{array}{c}1.18^{*} \\
(0.19)\end{array}$ & & $\begin{array}{c}0.51 \text { * } \\
(0.072)\end{array}$ & & & 0.25 & & \\
\hline & $\begin{array}{l}0.871^{*} \\
(0.18)\end{array}$ & & & $\begin{array}{l}0.633^{*} \\
(0.08)\end{array}$ & & 0.36 & & \\
\hline & $\begin{array}{l}0.485^{\star} \\
(0.24)\end{array}$ & & & & $\begin{array}{c}0.76^{\star} \\
(0.13)\end{array}$ & 0.25 & & \\
\hline & $\begin{array}{c}0.34^{*} \\
(0.16)\end{array}$ & $\begin{array}{c}0.74^{*} \\
(0.19)\end{array}$ & $\begin{array}{l}0.084 \\
(0.09)\end{array}$ & & & 0.41 & 3.87 & $6.43^{\star}$ \\
\hline & $\begin{array}{r}0.362 \\
(0.2)\end{array}$ & $\begin{array}{c}0.59^{*} \\
(0.12)\end{array}$ & & $\begin{array}{l}0.239 \\
(0.13)\end{array}$ & & 0.43 & $9.17^{*}$ & $10.32^{*}$ \\
\hline & $\begin{array}{l}0.383 \\
(0.22)\end{array}$ & $\begin{array}{c}0.86^{\star \dagger} \\
(0.11)\end{array}$ & & & $\begin{array}{r}-0.043 \\
(0.14)\end{array}$ & 0.41 & 2.71 & $5.84^{\star}$ \\
\hline \multirow[t]{7}{*}{$2 \mathrm{M}$} & $\begin{array}{c}0.33^{*} \\
(0.16)\end{array}$ & $\begin{array}{c}0.84^{\star \dagger} \\
(0.19)\end{array}$ & & & & 0.44 & $4.82^{*}$ & \\
\hline & $\begin{array}{c}0.80^{*} \\
(0.19)\end{array}$ & & $\begin{array}{c}0.66^{*} \\
(0.08)\end{array}$ & & & 0.43 & & \\
\hline & $\begin{array}{l}0.874^{*} \\
(0.19)\end{array}$ & & & $\begin{array}{c}0.64^{*} \\
(0.08)\end{array}$ & & 0.42 & & \\
\hline & $\begin{array}{l}0.561^{*} \\
(0.25)\end{array}$ & & & & $\begin{array}{c}0.74^{\star} \\
(0.12)\end{array}$ & 0.25 & & \\
\hline & $\begin{array}{c}0.35^{\star} \\
(0.17)\end{array}$ & $\begin{array}{c}0.49^{*} \\
(0.15)\end{array}$ & $\begin{array}{c}0.36^{\star} \\
(0.13)\end{array}$ & & & 0.48 & $14.65^{\star}$ & $10.22^{*}$ \\
\hline & $\begin{array}{l}0.393^{*} \\
(0.19)\end{array}$ & $\begin{array}{c}0.51^{*} \\
(0.13)\end{array}$ & & $\begin{array}{c}0.32^{*} \\
(0.14)\end{array}$ & & 0.47 & $10.95^{\star \star}$ & $12.51^{* *}$ \\
\hline & $\begin{array}{l}0.372 \\
(0.21)\end{array}$ & $\begin{array}{l}0.87^{\star \dagger} \\
(0.12)\end{array}$ & & & $\begin{array}{r}-0.046 \\
(0.13)\end{array}$ & 0.44 & 2.43 & $4.65^{\star *}$ \\
\hline \multirow[t]{7}{*}{$3 M$} & $\begin{array}{c}0.37^{*} \\
(0.18)\end{array}$ & $\begin{array}{l}0.84^{\star} \\
(0.2)\end{array}$ & & & & 0.42 & $5.06^{*}$ & \\
\hline & $\begin{array}{c}0.79^{*} \\
(0.21)\end{array}$ & & $\begin{array}{c}0.68^{*} \\
(0.09)\end{array}$ & & & 0.46 & & \\
\hline & $\begin{array}{l}0.924^{*} \\
(0.19)\end{array}$ & & & $\begin{array}{c}0.63^{*} \\
(0.08)\end{array}$ & & 0.45 & & \\
\hline & $\begin{array}{c}0.51^{*} \\
(0.24)\end{array}$ & & & & $\begin{array}{c}0.76^{*} \\
(0.13)\end{array}$ & 0.27 & & \\
\hline & $\begin{array}{c}0.5^{\star} \\
(0.12)\end{array}$ & $\begin{array}{c}0.33^{*} \\
(0.12)\end{array}$ & $\begin{array}{c}0.46^{*} \\
(0.17)\end{array}$ & & & 0.48 & $24.45^{\star \star}$ & $18.62^{\star *}$ \\
\hline & $\begin{array}{l}0.494^{*} \\
(0.19)\end{array}$ & $\begin{array}{c}0.39^{*} \\
(0.12)\end{array}$ & & $\begin{array}{c}0.4^{\star} \\
(0.13)\end{array}$ & & 0.48 & $20.87^{\star \star}$ & $24.98^{\star *}$ \\
\hline & $\begin{array}{r}0.27 \\
(0.19)\end{array}$ & $\begin{array}{c}0.77^{\star} \\
(0.11)\end{array}$ & & & $\begin{array}{r}0.1 \\
(0.11)\end{array}$ & 0.43 & 3.24 & $3.97^{\star *}$ \\
\hline
\end{tabular}


TABLE II

(Continued)

\begin{tabular}{|c|c|c|c|c|c|c|c|c|}
\hline Horizon & $\begin{array}{l}\alpha_{0} \\
c t .\end{array}$ & $\begin{array}{l}\alpha_{1} \\
I V\end{array}$ & $H V$ & $\begin{array}{c}\alpha_{2} \\
\text { EWMA }\end{array}$ & GARCH & $A d-R^{2}$ & F1-stat & F2-stat \\
\hline \multirow[t]{7}{*}{$6 \mathrm{M}$} & $\begin{array}{c}1.01^{*} \\
(0.39)\end{array}$ & $\begin{array}{c}0.62^{*} \\
(0.18)\end{array}$ & & & & 0.28 & $15.63^{* *}$ & \\
\hline & $\begin{array}{c}1.63^{*} \\
(0.34)\end{array}$ & & $\begin{array}{c}0.36 * \\
(0.13)\end{array}$ & & & 0.19 & & \\
\hline & $\begin{array}{l}1.509^{*} \\
(0.21)\end{array}$ & & & $\begin{array}{c}0.41^{*} \\
(0.09)\end{array}$ & & 0.28 & & \\
\hline & $\begin{array}{l}1.293^{*} \\
(0.25)\end{array}$ & & & & $\begin{array}{c}0.48^{*} \\
(0.12)\end{array}$ & 0.133 & & \\
\hline & $\begin{array}{c}0.93^{*} \\
(0.26)\end{array}$ & $\begin{array}{c}0.76^{*} \\
(0.21)\end{array}$ & $\begin{array}{r}-0.13 \\
(0.16)\end{array}$ & & & 0.28 & $12.67^{\star \star}$ & $11.38^{\star \star}$ \\
\hline & $\begin{array}{l}1.118^{*} \\
(0.21)\end{array}$ & $\begin{array}{l}0.31^{*} \\
(0.1)\end{array}$ & & $\begin{array}{c}0.26^{*} \\
(0.12)\end{array}$ & & 0.32 & $29.94^{* *}$ & $21.85^{\star *}$ \\
\hline & $\begin{array}{l}1.027^{*} \\
(0.23)\end{array}$ & $\begin{array}{c}0.61^{*} \\
(0.12)\end{array}$ & & & $\begin{array}{r}-0.015 \\
(0.11)\end{array}$ & 0.27 & $13.87^{\star \star *}$ & $8.83^{\star \star}$ \\
\hline
\end{tabular}

Panel B: AUD/USD

\begin{tabular}{|c|c|c|c|c|c|c|c|c|}
\hline \multirow[t]{2}{*}{$1 \mathrm{M}$} & $\begin{array}{r}0.30 \\
(0.26)\end{array}$ & $\begin{array}{c}0.84^{\star \dagger} \\
(0.091)\end{array}$ & & & & 0.48 & \multicolumn{2}{|l|}{$7.54^{\star}$} \\
\hline & $\begin{array}{l}1.01^{*} \\
(0.21)\end{array}$ & & $\begin{array}{c}0.54^{*} \\
(0.085)\end{array}$ & & & 0.29 & & \\
\hline & $\begin{array}{l}0.878^{*} \\
(0.17)\end{array}$ & & & $\begin{array}{l}0.596^{*} \\
(0.08)\end{array}$ & & 0.29 & & \\
\hline & $\begin{array}{l}0.449 \\
(0.23)\end{array}$ & & & & $\begin{array}{l}0.796^{*} \\
(0.12)\end{array}$ & 0.25 & & \\
\hline & $\begin{array}{l}0.307 \\
(0.25)\end{array}$ & $\begin{array}{l}0.89^{\star \dagger} \\
(0.11)\end{array}$ & $\begin{array}{l}-0.05 \\
(0.09)\end{array}$ & & & 0.48 & 2.24 & $7.52^{\star \star}$ \\
\hline & $\begin{array}{l}0.322 \\
(0.17)\end{array}$ & $\begin{array}{l}0.986^{\star \dagger} \\
(0.12)\end{array}$ & & $\begin{array}{r}-0.152 \\
(0.1)\end{array}$ & & 0.49 & 2.86 & $8.21^{* *}$ \\
\hline & $\begin{array}{l}0.766^{\star} \\
(0.19)\end{array}$ & $\begin{array}{l}1.294^{*} \\
(0.12)\end{array}$ & & & $\begin{array}{c}-0.668^{*} \\
(0.14)\end{array}$ & 0.51 & $17.34^{\star \star}$ & $27.75^{\star \star}$ \\
\hline $2 \mathrm{M}$ & $\begin{array}{c}0.42^{*} \\
(0.19)\end{array}$ & $\begin{array}{c}0.81^{*} \\
(0.09)\end{array}$ & & & & 0.48 & $4.97^{\star \star}$ & \\
\hline & $\begin{array}{l}0.91^{*} \\
(0.16)\end{array}$ & & $\begin{array}{c}0.60^{*} \\
(0.07)\end{array}$ & & & 0.36 & & \\
\hline & $\begin{array}{c}0.99^{*} \\
(0.16)\end{array}$ & & & $\begin{array}{l}0.564^{*} \\
(0.07)\end{array}$ & & 0.32 & & \\
\hline & $\begin{array}{l}0.719^{*} \\
(0.23)\end{array}$ & & & & $\begin{array}{c}0.69^{*} \\
(0.12)\end{array}$ & 0.21 & & \\
\hline & $\begin{array}{l}0.43^{*} \\
(0.18)\end{array}$ & $\begin{array}{c}0.78^{*} \\
(0.11)\end{array}$ & $\begin{array}{r}0.03 \\
(0.08)\end{array}$ & & & 0.48 & $5.01^{* *}$ & $3.96^{* *}$ \\
\hline & $\begin{array}{l}0.417^{*} \\
(0.16)\end{array}$ & $\begin{array}{l}0.92^{\star \dagger} \\
(0.13)\end{array}$ & & $\begin{array}{r}-0.101 \\
(0.11)\end{array}$ & & 0.49 & 4.53 & $10.32^{\star *}$ \\
\hline & $\begin{array}{c}0.969^{*} \\
(0.2)\end{array}$ & $\begin{array}{l}1.321^{*} \\
(0.11)\end{array}$ & & & $\begin{array}{c}-0.756^{\star} \\
(0.13)\end{array}$ & 0.54 & $27.93^{\star \star}$ & $22.54^{\star *}$ \\
\hline
\end{tabular}


TABLE II

(Continued)

\begin{tabular}{|c|c|c|c|c|c|c|c|c|}
\hline Horizon & $\begin{array}{l}\alpha_{0} \\
\text { ct. }\end{array}$ & $\begin{array}{l}\alpha_{1} \\
I V\end{array}$ & $H V$ & $\begin{array}{c}\alpha_{2} \\
\text { EWMA }\end{array}$ & GARCH & $A d-R^{2}$ & F1-stat & F2-stat \\
\hline \multirow[t]{7}{*}{$3 M$} & $\begin{array}{c}0.57^{*} \\
(0.18)\end{array}$ & $\begin{array}{c}0.76^{*} \\
(0.08)\end{array}$ & & & & 0.47 & $12.37^{\star \star}$ & \\
\hline & $\begin{array}{l}0.79^{\star} \\
(0.14)\end{array}$ & & $\begin{array}{c}0.66^{*} \\
(0.07)\end{array}$ & & & 0.47 & & \\
\hline & $\begin{array}{l}1.01^{*} \\
(0.15)\end{array}$ & & & $\begin{array}{l}0.565^{\star} \\
(0.06)\end{array}$ & & 0.40 & & \\
\hline & $\begin{array}{l}0.906^{\star} \\
(0.24)\end{array}$ & & & & $\begin{array}{l}0.619^{\star} \\
(0.11)\end{array}$ & 0.18 & & \\
\hline & $\begin{array}{c}0.60^{*} \\
(0.19)\end{array}$ & $\begin{array}{c}0.40^{*} \\
(0.12)\end{array}$ & $\begin{array}{c}0.34^{*} \\
(0.12)\end{array}$ & & & 0.50 & $15.63^{* \star}$ & $17.28^{\star *}$ \\
\hline & $\begin{array}{l}0.584^{*} \\
(0.15)\end{array}$ & $\begin{array}{l}0.606^{*} \\
(0.13)\end{array}$ & & $\begin{array}{l}0.156 \\
(0.11)\end{array}$ & & 0.49 & $10.42^{* *}$ & $9.23^{* \star}$ \\
\hline & $\begin{array}{l}1.088^{\star} \\
(0.19)\end{array}$ & $\begin{array}{c}1.215^{\star} \\
(0.1)\end{array}$ & & & $\begin{array}{c}-0.733^{\star} \\
(0.11)\end{array}$ & 0.55 & $35.87^{\star \star}$ & $24.21^{\star \star}$ \\
\hline \multirow[t]{7}{*}{$6 \mathrm{M}$} & $\begin{array}{c}1.11^{*} \\
(0.19)\end{array}$ & $\begin{array}{c}0.55^{*} \\
(0.08)\end{array}$ & & & & 0.34 & $61.45^{\star *}$ & \\
\hline & $\begin{array}{l}1.22^{*} \\
(0.18)\end{array}$ & & $\begin{array}{c}0.50^{*} \\
(0.09)\end{array}$ & & & 0.35 & & \\
\hline & $\begin{array}{l}1.398^{\star} \\
(0.16)\end{array}$ & & & $\begin{array}{l}0.415^{\star} \\
(0.06)\end{array}$ & & 0.31 & & \\
\hline & $\begin{array}{l}1.608^{*} \\
(0.24)\end{array}$ & & & & $\begin{array}{l}0.327^{\star} \\
(0.11)\end{array}$ & 0.06 & & \\
\hline & $\begin{array}{c}1.11^{*} \\
(0.19)\end{array}$ & $\begin{array}{c}0.27^{*} \\
(0.13)\end{array}$ & $\begin{array}{c}0.28^{*} \\
(0.14)\end{array}$ & & & 0.36 & $49.65^{\star \star}$ & $48.65^{\star \star}$ \\
\hline & $\begin{array}{l}1.114^{*} \\
(0.17)\end{array}$ & $\begin{array}{l}0.376^{*} \\
(0.11)\end{array}$ & & $\begin{array}{r}0.178 \\
(0.1)\end{array}$ & & 0.36 & $36.48^{* *}$ & $38.21^{\star \star}$ \\
\hline & $\begin{array}{l}1.833^{*} \\
(0.18)\end{array}$ & $\begin{array}{c}1.054^{\star \dagger} \\
(0.1)\end{array}$ & & & $\begin{array}{c}-0.746^{*} \\
(0.12)\end{array}$ & 0.48 & $14.64^{\star \star}$ & $59.35^{\star *}$ \\
\hline \multicolumn{9}{|c|}{ Panel C: GBP/USD } \\
\hline \multirow[t]{6}{*}{$1 \mathrm{M}$} & $\begin{array}{l}0.61^{*} \\
(0.26)\end{array}$ & $\begin{array}{c}0.65^{*} \\
(0.14)\end{array}$ & & & & 0.24 & $28.17^{\star *}$ & \\
\hline & $\begin{array}{l}1.39^{*} \\
(0.22)\end{array}$ & & $\begin{array}{c}0.29^{*} \\
(0.11)\end{array}$ & & & 0.08 & & \\
\hline & $\begin{array}{l}1.079^{*} \\
(0.19)\end{array}$ & & & $\begin{array}{l}0.45^{\star} \\
(0.1)\end{array}$ & & 0.13 & & \\
\hline & $\begin{array}{l}0.334 \\
(0.39)\end{array}$ & & & & $\begin{array}{l}0.615^{\star} \\
(0.19)\end{array}$ & 0.12 & & \\
\hline & $\begin{array}{c}0.62^{*} \\
(0.24)\end{array}$ & $\begin{array}{c}0.82^{*} \\
(0.12)\end{array}$ & $\begin{array}{l}-0.17 \\
(0.12)\end{array}$ & & & 0.25 & 4.43 & $19.12^{\star \star}$ \\
\hline & $\begin{array}{l}0.623^{*} \\
(0.2)\end{array}$ & $\begin{array}{l}0.832^{\star \dagger} \\
(0.15)\end{array}$ & & $\begin{array}{r}-0.199 \\
(0.15)\end{array}$ & & 0.25 & $6.08^{* *}$ & $17.84^{\star \star}$ \\
\hline
\end{tabular}


TABLE II

(Continued)

\begin{tabular}{|c|c|c|c|c|c|c|c|c|}
\hline Horizon & $\begin{array}{l}\alpha_{0} \\
c t .\end{array}$ & $\begin{array}{l}\alpha_{1} \\
I V\end{array}$ & $H V$ & $\begin{array}{c}\alpha_{2} \\
E W M A\end{array}$ & GARCH & $A d-R^{2}$ & F1-stat & F2-stat \\
\hline & $\begin{array}{l}0.928^{\star} \\
(0.36)\end{array}$ & $\begin{array}{l}0.791^{*} \\
(0.14)\end{array}$ & & & $\begin{array}{r}-0.301 \\
(0.29)\end{array}$ & 0.24 & $6.83^{\star *}$ & $18.69^{* *}$ \\
\hline \multirow[t]{7}{*}{$2 \mathrm{M}$} & $\begin{array}{l}1.13^{*} \\
(0.26)\end{array}$ & $\begin{array}{c}0.41^{*} \\
(0.13)\end{array}$ & & & & 0.12 & $52.63^{* *}$ & \\
\hline & $\begin{array}{c}1.74^{*} \\
(0.29)\end{array}$ & & $\begin{array}{r}0.13 \\
(0.12)\end{array}$ & & & 0.02 & & \\
\hline & $\begin{array}{c}1.608^{*} \\
(0.2)\end{array}$ & & & $\begin{array}{l}0.198 \\
(0.12)\end{array}$ & & 0.05 & & \\
\hline & $\begin{array}{l}1.156^{*} \\
(0.42)\end{array}$ & & & & $\begin{array}{l}0.42^{*} \\
(0.2)\end{array}$ & 0.05 & & \\
\hline & $\begin{array}{l}1.14^{*} \\
(0.28)\end{array}$ & $\begin{array}{c}0.71^{*} \\
(0.19)\end{array}$ & $\begin{array}{l}-0.33^{*} \\
(0.15)\end{array}$ & & & 0.17 & $14.89^{* *}$ & $44.73^{\star *}$ \\
\hline & $\begin{array}{l}1.081^{*} \\
(0.29)\end{array}$ & $\begin{array}{c}0.68^{\star} \\
(0.21)\end{array}$ & & $\begin{array}{r}-0.256 \\
(0.17)\end{array}$ & & 0.13 & $11.88^{* *}$ & $32.86^{\star *}$ \\
\hline & $\begin{array}{l}1.509^{*} \\
(0.42)\end{array}$ & $\begin{array}{c}0.62^{*} \\
(0.21)\end{array}$ & & & $\begin{array}{r}-0.397 \\
(0.32)\end{array}$ & 0.13 & $11.47^{* *}$ & $36.34^{* *}$ \\
\hline \multirow[t]{7}{*}{$3 \mathrm{M}$} & $\begin{array}{l}1.93^{*} \\
(0.27)\end{array}$ & $\begin{array}{r}0.11 \\
(0.09)\end{array}$ & & & & 0.01 & $106.43^{* *}$ & \\
\hline & $\begin{array}{c}2.2^{*} \\
(0.26)\end{array}$ & & $\begin{array}{l}-0.08 \\
(0.09)\end{array}$ & & & 0.01 & & \\
\hline & $\begin{array}{l}1.94^{*} \\
(0.15)\end{array}$ & & & $\begin{array}{r}0.05 \\
(0.06)\end{array}$ & & 0.02 & & \\
\hline & $\begin{array}{l}2.105^{*} \\
(0.32)\end{array}$ & & & & $\begin{array}{l}-0.04 \\
(0.15)\end{array}$ & 0.01 & & \\
\hline & $\begin{array}{l}1.94^{*} \\
(0.29)\end{array}$ & $\begin{array}{c}0.31^{*} \\
(0.16)\end{array}$ & $\begin{array}{l}-0.29^{\star} \\
(0.14)\end{array}$ & & & 0.05 & $47.85^{\star *}$ & $91.53^{\text {** }}$ \\
\hline & $\begin{array}{l}1.959^{*} \\
(0.27)\end{array}$ & $\begin{array}{r}-0.017 \\
(0.19)\end{array}$ & & $\begin{array}{l}0.051 \\
(0.12)\end{array}$ & & 0.01 & $34.88^{\star *}$ & $69.57^{\star \star}$ \\
\hline & $\begin{array}{l}2.207^{*} \\
(0.32)\end{array}$ & $\begin{array}{r}0.21 \\
(0.18)\end{array}$ & & & $\begin{array}{r}-0.309 \\
(0.26)\end{array}$ & 0.02 & $43.44^{* *}$ & $76.73^{\text {** }}$ \\
\hline \multirow[t]{5}{*}{$6 \mathrm{M}$} & $\begin{array}{l}2.51^{*} \\
(0.28)\end{array}$ & $\begin{array}{l}-0.11 \\
(0.16)\end{array}$ & & & & 0.04 & $176.81^{\star *}$ & \\
\hline & $\begin{array}{l}2.34^{*} \\
(0.23)\end{array}$ & & $\begin{array}{l}-0.15 \\
(0.12)\end{array}$ & & & 0.03 & & \\
\hline & $\begin{array}{l}2.099^{*} \\
(0.09)\end{array}$ & & & $\begin{array}{r}-0.037 \\
(0.05)\end{array}$ & & 0.01 & & \\
\hline & $\begin{array}{l}2.382^{*} \\
(0.25)\end{array}$ & & & & $\begin{array}{r}-0.176 \\
(0.14)\end{array}$ & 0.02 & & \\
\hline & $\begin{array}{c}2.56^{*} \\
(0.31)\end{array}$ & $\begin{array}{l}-0.04 \\
(0.18)\end{array}$ & $\begin{array}{l}-0.08^{*} \\
(0.16)\end{array}$ & & & 0.04 & $87.32^{* *}$ & $119.85^{\star \star}$ \\
\hline
\end{tabular}


TABLE II

(Continued)

\begin{tabular}{|c|c|c|c|c|c|c|c|c|}
\hline Horizon & $\begin{array}{l}\alpha_{0} \\
c t .\end{array}$ & $\begin{array}{l}\alpha_{1} \\
I V\end{array}$ & $H V$ & $\begin{array}{c}\alpha_{2} \\
\text { EWMA }\end{array}$ & GARCH & $A d-R^{2}$ & F1-stat & F2-stat \\
\hline & $\begin{array}{l}2.602^{*} \\
(0.29)\end{array}$ & $\begin{array}{r}-0.356 \\
(0.13)\end{array}$ & & $\begin{array}{l}0.095 \\
(0.07)\end{array}$ & & 0.05 & $83.12^{\star *}$ & $109.31^{\text {** }}$ \\
\hline & $\begin{array}{r}2.483^{*} \\
(0.27)\end{array}$ & $\begin{array}{r}-0.236 \\
(0.13)\end{array}$ & & & $\begin{array}{l}0.026 \\
(0.14)\end{array}$ & 0.04 & $85.63^{\star *}$ & $119.76^{\star \star}$ \\
\hline
\end{tabular}

Note. The table shows the regression estimates of the model:

$$
\ln \sigma_{t, T}^{\mathrm{AV}}=\alpha_{0}+\alpha_{1} \ln \sigma_{t, T}^{\mathrm{QIV}}+\alpha_{2} \ln \sigma_{t, T}^{\mathrm{HV}}+u_{t}
$$

where $\sigma_{t, T}^{\mathrm{AV}}$ denotes the actual (realized) volatility over the period $t$ to $t+T, \sigma_{t, T}^{\mathrm{OIV}}$ is the quoted implied volatility that is observed at time $t$ for a contract with maturity at $t+T$, and $\sigma_{t, T}^{\mathrm{HV}}$ is the volatility that is forecast over the period $t$ to $t+T$, which is computed using the historical standard deviation, $\operatorname{GARCH}(1,1)$, or RiskMetrics EWMA models. The historical standard deviation was calculated using daily exchange rates over the 23 working days (1M), 46 Days (2M), 69 Days (3M), and 123 Days (6M) prior to the forecast. The GARCH forecasts are based on a rolling $\operatorname{GARCH}(1,1)$ model. The EWMA forecasts are based on a model with $\lambda=0.94$. The results are based on 1015 daily data per currency pair per maturity period from June 5, 1996, to April 25, 2000. The Newey-West heteroskedasticity and autocorrelation adjusted standard errors are in parenthesis. The $F 1$-statistic tests the hypothesis that $\alpha_{0}=0$ and $\alpha_{1}=1$. The F2-statistic tests the hypothesis that $\alpha_{0}=0$, $\alpha_{1}=1$, and $\alpha_{2}=0$

${ }^{*}$ Significantly different from zero at the $5 \%$ level; ${ }^{*}$ Significantly different from zero at the $1 \%$ level; ${ }^{\dagger}$ Not significantly different from one at the $5 \%$ level.

GBP/USD at the 3-month and the 6-month horizon) have estimates of $\alpha_{1}$ that are statistically different than zero. The statistical and economic significance of $\alpha_{1}$, however, decreases with maturity. The 1-month forecasting horizon has the largest value of $\alpha_{1}$, which ranges from 0.65 for GBP/USD to 0.84 for AUD/USD, and the 6-month forecasting horizon has the smallest value of $\alpha_{1}$, which ranges from -0.11 for GBP/USD to 0.62 for USD/JPY. Furthermore, $\alpha_{1}$ is not significantly different from one for the 1-month USD/JPY and AUD/USD forecasting horizon. However, the $F$-test rejects the unbiasedness hypothesis of $\alpha_{0}=0$ and $\alpha_{1}=1$ for all of the currencies and maturities except for USD/JPY 1-month. Thus, quoted implied volatility contains significant information about the future volatility, and this information decreases as the forecasting horizon lengthens.

The results for historical standard deviation are mixed. The predictive power of historical standard deviation is relatively weaker. However, for USD/JPY and AUD/USD, the predictive power increases with the forecasting horizon from 1 month to 3 months.

The difference in the prediction power of historical standard deviation and quoted implied volatility also is evident from the values of the adjusted $R^{2}$. For instance, across all currencies for the 1-month horizon, 
the adjusted $R^{2}$ values are much greater for quoted implied volatility than for historical volatility. However, the difference diminishes with a longer forecasting horizon.

When GARCH or EWMA volatilities are regressed independently, both have high explanatory power across forecasting horizons and currency pairs, but not as good as that of quoted implied volatility. The largest coefficients, which correspond to the 1-month horizon, are between 0.45 for GBP/USD and 0.633 for USD/JPY for the EWMA, and between 0.615 for GBP/USD and 0.796 for AUD/USD for the GARCH. The univariate results in Table II show that the slopes of the GARCH and EWMA forecasts are comparable to the slopes of the historical standard deviation, but are smaller than the slope of quoted implied volatility. This finding also is supported by a higher $R^{2}$ for the quoted implied volatility regression.

\section{Encompassing Regression Tests}

The results in the previous section show that the quoted implied volatility is significantly better than the alternative volatility forecasts. In this section, forecast-encompassing tests that are based on Equation 5 are employed to determine whether quoted implied volatility incorporates all of the relevant information in competing forecasts, namely whether it is informationally efficient. Table II presents the results.

When both the historical standard deviation and the quoted implied volatility are employed, the statistical evidence shows that the quoted implied volatility subsumes the historical volatility for the 1 - and 2-month forecasting horizons. However, the same is not observed for the 3 - and 6-month forecasting horizons. For the 1-month contract, $\alpha_{1}$ ranges from 0.74 (USD/JPY) to 0.89 (AUD/USD), and the quoted implied volatility is an unbiased estimate of the actual volatility for all three currencies. In contrast, $\alpha_{2}$ is statistically and economically insignificant across all currencies. However, as the forecasting horizon increases, the economic and statistical significance of $\alpha_{1}$ decreases and that of $\alpha_{2}$ increases, with the results being similar across the three currency pairs. These results are consistent with the hypothesis that the quoted implied volatility has good predictive power for future volatility. However, the statistical evidence on the quoted implied volatility as an unbiased predictor of actual volatility is mixed. Quoted implied volatility is an unbiased predictor of future volatility at the 1-month horizon, but exhibits bias for all other forecasting horizons. The quoted implied volatility also appears to be an informationally inefficient forecast of 
actual volatility for each forecasting horizon and currency pair, with the associated F-statistics being greater than the critical value of 3.8.

Table II also shows that the quoted implied volatility contains a substantial amount of information when compared to GARCH and EWMA volatility forecasts. The results are consistent across forecasting horizons and currency pairs. For example, at the 1-month horizon for the USD/JPY when EWMA is regressed jointly with the quoted implied volatility, $\alpha_{1}$ is 0.59 and $\alpha_{2}$ is only 0.239 . At the 6-month horizon for the AUD/USD when GARCH is regressed jointly with the quoted implied volatility, $\alpha_{1}$ is 1.054 and $\alpha_{2}$ is only -0.746 . Furthermore, quoted implied volatility is an unbiased estimate at the 1- and 2-month horizons for the USD/JPY when regressed with GARCH, and for the AUD/USD when regressed with EWMA. The adjusted $R^{2}$ values also are noticeably higher when the quoted implied volatility is included. For example, at the 1-month horizon for the AUD/USD when EWMA and GARCH are regressed independently, the adjusted $R^{2}$ values are 0.29 and 0.25 , respectively. However, when quoted implied volatility is included, the adjusted $R^{2}$ values improve to 0.49 and 0.51 , respectively.

Overall, the quoted implied volatility remains the best forecast, even when matched with more-sophisticated time-series-based volatility estimators.

The evidence suggests that the ability of quoted implied volatility to forecast future volatility is surprisingly good for the short-term forecasting horizon. However, the quoted implied volatility does not perform as well in forecasting longer horizon future volatility. There are several possible explanations for this. Firstly, it is commonly accepted that market traders are better in identifying and analyzing the fundamentals (e.g., central bank policies or macroeconomic data) and technical factors (e.g., market sentiments or trends) that affect short-term volatility than affect long-term volatility. Secondly, the recent behavioral literature indicates that investors in the stock market suffer from overconfidence and extrapolative biases, and it is plausible that currency traders experience the same behavior, which might impair their forecasting ability.

Finally, as suggested by Figlewski (1997), although traders may make rational forecasts of future volatility, the lack of market liquidity, the presence of transaction costs, and the difficulty of executing arbitrage opportunities may prevent option prices from accurately reflecting the best forecast of future volatility. The information on the actual trading volume for options with different maturity periods is not available. However, discussions with several OTC currency option traders suggest that longer maturity option contracts are relatively less liquid than the shorter contracts. The 1-month contract, which is the 
most liquid and easiest to hedge with delta transactions (cash or futures), offers the best volatility forecast. In contrast, the least liquid 3- and 6-month contracts provide the worst forecasts.

\section{ROBUSTNESS TESTS}

Further tests are conducted to verify the robustness of the results to alternative sampling frequencies and methods of evaluating forecast accuracy.

\section{Volatility Forecasting with Monthly Sampling}

This section determines how sensitive the results are to the sample frequency. The tests that have been performed so far use daily volatility data that introduces overlaps in the error terms that tend to bias the OLS regressions. The reason for this bias is that each observation in a particular volatility time series is constructed according to a moving window of $N$ daily returns that differs from the previous window by just one return. To assess this effect, new series of one-month-ahead forecasts with nonoverlapping periods are constructed based on monthly sampling.

For all of the currencies, the study re-estimates the univariate and encompassing regressions based on Equation 5; the results are presented in Table III. Because the non-overlapping series are one-month volatility

TABLE III

Information Content of Quoted Implied Volatility vs. Historical, GARCH, and EWMA Volatility (Monthly Sampling)

\begin{tabular}{|c|c|c|c|c|c|c|c|c|}
\hline Horizon & $\begin{array}{l}\alpha_{0} \\
c t .\end{array}$ & $\begin{array}{l}\alpha_{1} \\
I V\end{array}$ & $H V$ & $\begin{array}{c}\alpha_{2} \\
\text { EWMA }\end{array}$ & GARCH & $A d-R^{2}$ & F1-stat & F2-stat \\
\hline \multicolumn{9}{|c|}{ Panel A: USD/JPY } \\
\hline \multirow[t]{7}{*}{$1 \mathrm{M}$} & $\begin{array}{r}0.23 \\
(0.35)\end{array}$ & $\begin{array}{l}0.87^{\star \dagger} \\
(0.14)\end{array}$ & & & & 0.35 & $4.1^{*}$ & \\
\hline & $\begin{array}{c}1.41^{*} \\
(0.32)\end{array}$ & & $\begin{array}{c}0.41^{*} \\
(0.12)\end{array}$ & & & 0.15 & & \\
\hline & $\begin{array}{c}0.93^{*} \\
(0.28)\end{array}$ & & & $\begin{array}{c}0.61^{\star} \\
(0.11)\end{array}$ & & 0.28 & & \\
\hline & $\begin{array}{r}0.63 \\
(0.59)\end{array}$ & & & & $\begin{array}{l}0.71^{*} \\
(0.23)\end{array}$ & 0.16 & & \\
\hline & $\begin{array}{r}0.21 \\
(0.36)\end{array}$ & $\begin{array}{l}0.82^{\star \dagger} \\
(0.16)\end{array}$ & $\begin{array}{l}0.064 \\
(0.12)\end{array}$ & & & 0.35 & 0.65 & 2.58 \\
\hline & $\begin{array}{r}0.24 \\
(0.32)\end{array}$ & $\begin{array}{l}0.64^{\star} \\
(0.18)\end{array}$ & & $\begin{array}{r}0.23 \\
(0.14)\end{array}$ & & 0.35 & 2.32 & $4.85^{\star}$ \\
\hline & $\begin{array}{r}0.23 \\
(0.46)\end{array}$ & $\begin{array}{l}0.81^{\text {*† }} \\
(0.17)\end{array}$ & & & $\begin{array}{r}0.06 \\
(0.21)\end{array}$ & 0.35 & 0.59 & 2.44 \\
\hline
\end{tabular}




\section{TABLE III}

(Continued)

Information Content of Quoted Implied Volatility vs. Historical, GARCH, and EWMA Volatility (Monthly Sampling)

\begin{tabular}{|c|c|c|c|c|c|c|c|c|}
\hline Horizon & $\begin{array}{l}\alpha_{0} \\
c t .\end{array}$ & $\begin{array}{l}\alpha_{1} \\
I V\end{array}$ & $H V$ & $\begin{array}{c}\alpha_{2} \\
\text { EWMA }\end{array}$ & GARCH & $A d-R^{2}$ & F1-stat & F2-stat \\
\hline \multicolumn{9}{|c|}{ Panel B: AUD/USD } \\
\hline \multirow[t]{7}{*}{$1 \mathrm{M}$} & $\begin{array}{r}0.2 \\
(0.24)\end{array}$ & $\begin{array}{l}0.89^{\star \dagger} \\
(0.1)\end{array}$ & & & & 0.48 & 2.92 & \\
\hline & $\begin{array}{c}1.12^{*} \\
(0.31)\end{array}$ & & $\begin{array}{c}0.49 * \\
(0.13)\end{array}$ & & & 0.23 & & \\
\hline & $\begin{array}{c}0.89 * \\
(0.33)\end{array}$ & & & $\begin{array}{c}0.59^{\star} \\
(0.14)\end{array}$ & & 0.26 & & \\
\hline & $\begin{array}{r}0.55 \\
(0.61)\end{array}$ & & & & $\begin{array}{c}0.76^{*} \\
(0.26)\end{array}$ & 0.17 & & \\
\hline & $\begin{array}{r}0.25 \\
(0.24)\end{array}$ & $\begin{array}{l}0.89^{* \dagger} \\
(0.16)\end{array}$ & $\begin{array}{l}-0.01 \\
(0.13)\end{array}$ & & & 0.48 & 0.49 & 1.82 \\
\hline & $\begin{array}{r}0.22 \\
(0.24)\end{array}$ & $\begin{array}{l}1.00^{\star \dagger} \dagger \\
(0.14)\end{array}$ & & $\begin{array}{r}-0.12 \\
(0.14)\end{array}$ & & 0.48 & 0.51 & 1.74 \\
\hline & $\begin{array}{r}0.37 \\
(0.34)\end{array}$ & $\begin{array}{c}0.9^{\star \dagger} \\
(0.15)\end{array}$ & & & $\begin{array}{l}-0.08 \\
(0.23)\end{array}$ & 0.47 & 0.89 & 2.19 \\
\hline \multicolumn{9}{|c|}{ Panel C: GBP/USD } \\
\hline \multirow[t]{7}{*}{$1 \mathrm{M}$} & $\begin{array}{r}0.39 \\
(0.29)\end{array}$ & $\begin{array}{c}0.76^{\star \dagger} \\
(0.14)\end{array}$ & & & & 0.26 & $10.91^{*}$ & \\
\hline & $\begin{array}{c}1.37^{*} \\
(0.29)\end{array}$ & & $\begin{array}{c}0.31^{*} \\
(0.14)\end{array}$ & & & 0.07 & & \\
\hline & $\begin{array}{c}1.02 * \\
(0.22)\end{array}$ & & & $\begin{array}{c}0.48^{\star} \\
(0.11)\end{array}$ & & 0.15 & & \\
\hline & $\begin{array}{c}1.57^{*} \\
(0.68)\end{array}$ & & & & $\begin{array}{r}0.21 \\
(0.32)\end{array}$ & 0.02 & & \\
\hline & $\begin{array}{c}0.77^{*} \\
(0.24)\end{array}$ & $\begin{array}{l}0.91^{* \dagger} \\
(0.15)\end{array}$ & $\begin{array}{c}-0.35^{\star} \\
(0.12)\end{array}$ & & & 0.28 & $6.39^{*}$ & $13.42^{*}$ \\
\hline & $\begin{array}{r}0.38 \\
(0.31)\end{array}$ & $\begin{array}{c}0.85^{\star \dagger} \\
(0.37)\end{array}$ & & $\begin{array}{r}-0.09 \\
(0.28)\end{array}$ & & 0.25 & 1.23 & $6.83^{\star}$ \\
\hline & $\begin{array}{r}0.61 \\
(0.34)\end{array}$ & $\begin{array}{c}0.89^{\star \dagger} \\
(0.32)\end{array}$ & & & $\begin{array}{l}-0.25 \\
(0.42)\end{array}$ & 0.25 & 2.08 & $7.08^{*}$ \\
\hline
\end{tabular}

Note. The table shows the regression estimates of the model:

$$
\ln \sigma_{t, T}^{\mathrm{AV}}=\alpha_{0}+\alpha_{1} \ln \sigma_{t, T}^{\mathrm{QIV}}+\alpha_{2} \ln \sigma_{t, T}^{\mathrm{HV}}+u_{t}
$$

where $\sigma_{t, T}^{\mathrm{AV}}$ denotes the actual (realized) volatility over the period $t$ to $t+T, \sigma_{t, T}^{\mathrm{QIV}}$ is the quoted implied volatility that is observed at time $t$ for a contract with maturity at $t+T$, and $\sigma_{t, T}^{\mathrm{HV}}$ is the volatility that is forecast over the period $t$ to $t+T$, and is computed using the historical standard deviation, $\operatorname{GARCH}(1,1)$, or RiskMetrics EWMA models. The $\mathrm{GARCH}$ forecasts are based on a rolling $\mathrm{GARCH}(1,1)$ model. The results are based on 51 monthly data per currency pair per maturity period form June 5, 1996, to April 25, 2000. The Newey-West heteroskedasticity and autocorrelation adjusted standard errors are in parenthesis. The F1-statistic tests the hypothesis that $\alpha_{0}=0$ and $\alpha_{1}=1$. The F2-statistic tests the hypothesis that $\alpha_{0}=0, \alpha_{1}=1$ and $\alpha_{2}=0$.

*Significantly different from zero at the $5 \%$ level.

${ }^{\dagger}$ Not significantly different from one at the $5 \%$ level. 
forecasts, the results from Table III are directly comparable with the results from Table II, which correspond to the one-month forecasting horizon. The results that correspond to the univariate regressions for all three currencies show small increases in the coefficients that correspond to the quoted implied volatility and decreases in those that correspond to the historical standard deviation and GARCH. As before, the quoted implied volatility is an unbiased estimate of future volatility, and the historically based volatility forecasts have high explanatory power. Interestingly, the adjusted $R^{2}$ values in Table III are lower than those in Table II, which suggests that the volatility forecasts explain less of the variation in the actual volatility for one-month sampling than is explained in daily sampling.

When implied volatility is regressed jointly with the other three volatility forecasts, there is a small increase in the slopes of the implied volatility, but no change in the slopes of the alternative forecasts when compared to the corresponding values from Table II. The information value of implied volatility is supported further by lower F1 and F2 statistics, with eight out of the nine $F 1$ statistics and five out of the nine F2 statistics being insignificant at the 5\% level. The adjusted $R^{2}$ values in Table III for all three of the multivariate regressions that correspond to USD/JPY are smaller than those in Table II, whereas those that correspond to the other two currencies experience no change.

Overall, the results in this section are qualitatively similar to those that were reported in the previous section, which suggests that the findings are robust with respect to the sampling frequency.

\section{Alternative Measures of Forecast Accuracy}

The robustness of the results is checked further by two alternative forecast-evaluation methods. The statistics that correspond to the daily volatility series are presented in Panel A of Table IV, and those for the monthly series are presented in Panel B. Firstly, the root-mean-squared error (RMSE) for the quoted implied volatility, historical standard deviation, GARCH, and EWMA volatility estimators are computed. Because RMSE depends on the scale of the forecast variables, it should be used as a relative measure to compare forecasts of the same option only. For both the daily and monthly series, the RMSE results indicate that, over both the 1- and 2-month horizons, quoted implied volatility outperforms any of the measures that are based on historical data, but performs equally well over the 3-and 6-month horizons. The results are qualitatively similar across currencies. 
TABLE IV

Forecast Accuracy of Alternative Volatility Forecasts

\begin{tabular}{|c|c|c|c|c|c|c|c|}
\hline \multirow[b]{2}{*}{ Horizon } & \multirow[b]{2}{*}{ Forecast } & \multicolumn{2}{|c|}{ USD/JPY } & \multicolumn{2}{|c|}{$A U D / U S D$} & \multicolumn{2}{|c|}{ GBP/USD } \\
\hline & & RMSE & $H L N$ & RMSE & $H L N$ & RMSE & $H L N$ \\
\hline \multicolumn{8}{|c|}{ Panel A: Daily Sampling } \\
\hline \multirow[t]{4}{*}{$1 \mathrm{M}$} & QV & 0.279 & - & 0.253 & - & 0.238 & - \\
\hline & HV & 0.316 & $-9.66^{\star}$ & 0.294 & $-11.31^{*}$ & 0.259 & $-4.78^{*}$ \\
\hline & GARCH & 0.312 & $-11.07^{\star}$ & 0.304 & $-9.68^{*}$ & 0.253 & $-3.96^{*}$ \\
\hline & EWMA & 0.289 & $-4.73^{\star}$ & 0.293 & $-11.41^{\star}$ & 0.252 & $-3.58^{*}$ \\
\hline \multirow[t]{4}{*}{$2 \mathrm{M}$} & QV & 0.243 & - & 0.227 & - & 0.197 & - \\
\hline & HV & 0.249 & $-2.57^{*}$ & 0.253 & $-11.68^{*}$ & 0.208 & $-5.13^{*}$ \\
\hline & GARCH & 0.287 & $-11.44^{\star}$ & 0.283 & $-13.21^{*}$ & 0.203 & $-3.72^{*}$ \\
\hline & EWMA & 0.256 & $-3.82^{*}$ & 0.261 & $-13.34^{*}$ & 0.201 & $-3.51^{*}$ \\
\hline \multirow[t]{4}{*}{$3 \mathrm{M}$} & QV & 0.235 & - & 0.206 & - & 0.152 & - \\
\hline & HV & 0.225 & 1.05 & 0.206 & -1.84 & 0.152 & -1.75 \\
\hline & GARCH & 0.262 & $-8.83^{\star}$ & 0.259 & $-12.93^{*}$ & 0.153 & $-4.88^{*}$ \\
\hline & EWMA & 0.238 & $-1.97^{\star}$ & 0.222 & $-9.33^{*}$ & 0.153 & $-4.53^{*}$ \\
\hline \multirow[t]{4}{*}{$6 \mathrm{M}$} & QV & 0.217 & - & 0.192 & - & 0.097 & - \\
\hline & HV & 0.229 & $-13.85^{\star}$ & 0.192 & 1.12 & 0.098 & $-2.84^{\star}$ \\
\hline & GARCH & 0.238 & $-4.83^{*}$ & 0.231 & $-4.22^{*}$ & 0.099 & $-3.53^{*}$ \\
\hline & EWMA & 0.226 & $-9.53^{\star}$ & 0.197 & $-2.44^{\star}$ & 0.099 & $-3.70^{\star}$ \\
\hline \multicolumn{8}{|c|}{ Panel B: Monthly Sampling } \\
\hline \multirow[t]{4}{*}{$1 \mathrm{M}$} & QV & 0.301 & - & 0.287 & - & 0.223 & - \\
\hline & $\mathrm{HV}$ & 0.373 & $-2.86^{\star}$ & 0.343 & $-2.68^{\star}$ & 0.261 & $-2.42^{*}$ \\
\hline & GARCH & 0.334 & $-2.31^{*}$ & 0.32 & $-2.36^{\star}$ & 0.262 & $-2.75^{\star}$ \\
\hline & EWMA & 0.315 & $-1.99^{\star}$ & 0.304 & $-2.08^{*}$ & 0.239 & $-2.06^{*}$ \\
\hline
\end{tabular}

Note. This table shows the RMSE (Root-Mean-Squared Error) of the quoted implied volatility, historical standard deviation, $\operatorname{GARCH}(1,1)$, and EWMA volatility estimators for the three currency pairs. It also depicts the Harvey, Leybourne, and Newbold (HLN) statistic on the null hypothesis of the equal forecast performance of quoted implied volatility and the alternative historical data-based estimators. The HLN statistic is compared to a critical value from student $t$-distribution. Panel A presents the results that correspond to the daily series and four forecasting horizons. Panel B shows the results for the monthly series and a one-month horizon.

*Significantly different from zero at the $5 \%$ level.

Although the RMSE forecast evaluation is common in the forecasting literature, it has several limitations. Fair and Schiller (1990) showed that when even one RMSE is higher than the other, it can contain information that is not present in the forecast with lower RMSE. Furthermore, when the RMSEs are very close, they cannot be used to distinguish superior forecast accuracy among several competing models.

An approach that was proposed by Harvey, Leybourne, and Newbold (1997) (HLN) can be used to achieve further insights into the predictive power of quoted implied volatility as compared to the alternative forecasts. The HLN method is a modified version of the Diebold and 
Mariano (1995) test, which is an asymptotic test of the null hypothesis of no difference in the accuracy of two competing estimators, which allows the forecast errors to be non-Gaussian, non-zero mean, and serially and contemporaneously correlated. In contrast to other methods, this test does not impose serious restrictions and is not sensitive to the non-normal properties of forecast errors. Furthermore, the HLN test is designed to correct for autocorrelation in the error series, which may result from the overlapping observations. The HLN statistics are compared to the critical value from a Student's $t$-distribution with $(N-1)$ degrees of freedom. ${ }^{11}$

Table IV also reports the results of the HLN test of the accuracy of quoted implied volatility against the three historically based volatility estimators. A negative and significant statistic indicates that quoted implied volatility is a better forecast than the alternative. For example, in Panel A, the AUD/USD quoted implied volatility is a better forecast than historical volatility for the 1- and 2-month horizon (with HLN statistics of -11.31 and -11.68 ), but not for the 3-and 6-month horizons (with HLN statistics of -1.84 and 1.12). Furthermore, the HLN statistics show that implied volatility performs better than GARCH and EWMA for all currencies and horizons. The results in Panel B practically match those in Panel A (the 1-month horizon), which indicates that the results are not sensitive to the sampling frequency.

Overall, these results are consistent with the findings that quoted implied volatility is the best forecast over short horizons and is at least as good as historically based volatility forecasts over long horizons.

\section{CONCLUSION}

The evidence shows that quoted implied volatility is an unbiased estimator of future volatility at the 1-month horizon, but its predictive power decreases with longer horizons. The results are consistent with the Figlewski (1997) hypothesis that the informational content of quoted implied volatility is related positively to liquidity. The 1 -month contract is the most liquid, and arbitrage is relatively easy to implement at the least cost, but market liquidity drops for contracts with longer maturities. The results also indicate that the quoted implied volatility has more predictive power than the historical standard deviation, RiskMetrics, and GARCH-based volatility forecasts across all of the currency pairs and

\footnotetext{
${ }^{11}$ The HLN statistic is defined as: $S=\sqrt{\frac{N+1-2 h+N^{-1}(h-1)}{N}} \frac{\bar{d}}{\sqrt{V(\bar{d})}}$, where $N$ is the number of squared error observations, $h$ is the number of days in the forecast horizon, $d$ is the sample mean of the difference in squared errors, and $V(\bar{d})$ is the asymptotic variance of $d$.
} 
forecasting horizons. Overall, quoted implied volatility subsumes the other forecasts at the shorter horizons, and it is as good at the longer horizons.

Although the two sets of results are not strictly comparable for the 1-month contract, it is worthwhile to note that the results of this study are a significant improvement over those of previous studies. This study finds that the quoted implied volatility is an unbiased estimate for all currencies, with an average slope coefficient that is above 0.83 , and an adjusted $R^{2}$ value of greater than 0.4 , as compared to-for exampleJorion (1995), who reported slopes of between 0.5 and 0.7 , and an adjusted $R^{2}$ value that was not greater than 0.15 . Possible explanations of the differences in the results are: (i) the importance of measurement errors, and (ii) the higher liquidity on the OTC market, which is consistent with the Figlewski (1997) liquidity hypothesis.

\section{BIBLIOGRAPHY}

Amin, K. I., \& Ng, V. K. (1997). Inferring future volatility from the information in implied volatility in Eurodollar options: A new approach. Review of Financial Studies, 10, 333-367.

Bank for International Settlement. (1999). Central bank survey of foreign exchange and derivatives market activity 1998. Basle: Author.

Bank for International Settlement. (2000). BIS quarterly review-International banking and financial market developments. Basle: Author.

Bates, D. (1996). Jumps \& stochastic volatility: Exchange rate processes implicit in Deutsche mark options. Review of Financial Studies, 9(1), 69-107.

Black, F., \& Scholes, M. (1973). The pricing of options and corporate liabilities. Journal of Political Economy, 81, 637-654.

Bodurtha, J., \& Shen, Q. (1995). Historical and implied measures of "value at risk": The DM and yen case (Working Paper). University of Michigan.

Breuer, J., \& Wohar, M. (1996). The road less travelled: Institutional aspects of data and their influence on empirical estimates with an application to tests of forward rate unbiasdeness. Economic Journal, 106, 26-38.

Campa, J., \& Chang, K. (1995). Testing the expectations hypothesis on the term structure of volatilities in foreign exchange options. Journal of Finance, 50, 529-547.

Campa, J., \& Chang, K. (1998). The forecasting ability of correlations implied in foreign exchange options. Journal of International Money and Finance, $17,855-880$.

Canina, L., \& Figlewski, S. (1993). The informational content of implied volatility. Review of Financial Studies, 6, 659-681.

Christensen, B. J., \& Prabhala, N. R. (1998). The relation between implied and realized volatility. Journal of Financial Economics, 50, 125-150.

Day, T., \& Lewis, C. (1992). Stock market volatility and the information content of stock index option. Journal of Econometrics, 52, 267-287. 
Diebold, F., \& Mariano, R. (1995). Comparing predictive accuracy. Journal of Business and Economic Statistics, 13, 253-263.

Fair, R., \& Shiller, R. (1990). Comparing information in forecasts from econometric models. American Economic Review, 80, 375-389.

Figlewski, S. (1997). Forecasting volatility. Financial Markets, Institutions \& Instruments. Volume 6(1). New York: New York University Salomon Center.

Fleming, J. (1998). The quality of market volatility forecasts implied by S\&P 100 index option prices. Journal of Empirical Finance, 5, 317-345.

Guo, D. (1998). The risk premium of volatility implicit in currency options. Journal of Business and Economic Statistics, 16, 498-507.

Harvey, D., Leybourne, S., \& Newbold, P. (1997). Testing the equality of prediction mean squared errors. International Journal of Forecasting, 13, 281-291.

Jorion, P. (1995). Predicting volatility in the foreign exchange market. Journal of Finance, 50, 507-528.

Kroner, K., Kneafsey, K., \& Claessens, S. (1994). Forecasting volatility in commodity markets. Journal of Forecasting, 14, 77-95.

Morgan, J. P. (1996). RiskMetrics ${ }^{\mathrm{TM}}$-Technical document (4th ed.). New York: Morgan Guaranty Trust Company.

Newey, W., \& West, K. (1987). Hypothesis testing with efficient method of moments estimation. International Economic Review, 28, 777-787.

Poteshman, A. (2000). Forecasting future variance from option prices (Working Paper). University of Illinois, Urbana-Champaign.

Scott, L. O. (1992). The information content of prices in derivative security market. IMF Staff Papers, 39, 596-625.

Taylor, J. W. (1999). Evaluating volatility and interval forecasts. Journal of Forecasting, 18, 111-128.

Taylor, S., \& Xu, X. (1997). The incremental volatility information in one million foreign exchange quotations. Journal of Empirical Finance, 4, $317-349$.

Xu, X., \& Taylor, S. (1994). The term structure of volatility implied by foreign exchange options. Journal of Financial and Quantitative Analysis, 29, $57-74$.

Xu, X., \& Taylor, S. (1995). Conditional volatility and the informational efficiency of the PHLX currency options market. Journal of Banking and Finance, 19, 803-821. 